\title{
The Food Industry in Ghana: Demystifying the Innovation and Quality Conundrum
}

\author{
Ernest Kwame Affum ${ }^{1 *} \quad$ Professor Haisu Wang ${ }^{2}$ \\ 1.School of Business Administration, Department of Industrial Economics, Zhongnan University of Economics \\ and Law, Hubei, China 430073 \\ 2.School of Business Administration, Department of Industrial Economics, and Centre for Intellectual property \\ Valuation, Zhongnan University of Economics and Law, Hubei, China 430073
}

\begin{abstract}
Most part of the food industry remains a "black box". Adding to it is the level of confusion that surrounds the industry in Ghana. The food industry in Ghana is just at the take off stage of its development. Meanwhile the country plays a vital role in the international arena, thereby heightening the debate over the need for total quality management (TQM) and innovation in the industry, especially proffering a model that can help to properly judge activities of the industry. That said, this paper using extensive review of literature has established the Dynamic Quality Model (DQM) and the Sustainable Innovation Model (SIM) as measures and analytical frameworks for quality and innovation. The DQM comprises nineteen variables that are grouped into two categories - endogenous and exogenous factors. The SIM however comprises eight variables. The study concludeS that the organizational factors, market factors and government are needed to effectively understand and analyze. Also, quality was considered highly essential if an innovation is to be absorbed by the market and help to achieve long run total factor productivity.
\end{abstract}

Keywords: Food Service; Industry; Innovation; Total Quality Management; Ghana

DOI: $10.7176 / \mathrm{JESD} / 10-4-03$

\section{Introduction}

Achieving a high level industrial output in a developing country continues to be a nightmare for organization leaders, industry players, regulators and governments at large. This requires a mix of variables to unlock the seemingly impenetrable challenge. Whiles stakeholders ponder on how to unravel the conundrum; consumers continue to mount incessant pressure, especially in relation to quality, on enterprises and governments alike. Most often, governments have focused on the industrial side to stimulate enterprise activities. The pinhole is to get industry to increase their level of productivity through innovation. The problem becomes more pronounced when innovation is seen as quality, yet quality practices leave much to be desired.

Stimulating industrial output through activities of the food industry is something not many governments in less economically developed countries (LEDCs) would consider due to a misconception that the sub industry has very little to contribute to gross domestic product (GDP). However, in the US alone, the restaurant industry has over the past 60 years seen an exponential increase in its contribution to GDP, considering the percentage of the industry in the food dollar, from $25 \%$ to $48 \%$ in 1955 and 2017, respectively. The industry has yielded $\$ 42.8$ billion in 1970 to an estimated amount of $\$ 798.70$ billion in 2017 while employment was predicted to reach 16.3 million in the same year from 25.5 million in 2007 (U. S. National Restaurant Association, 2017).

It has been estimated that about $20-25 \%$ of household food expenditure in Less Developed Countries (LDCs) are acquired from outside the home. Whiles this is convenient and affordable, there is a high level of contaminating diseases contracted due to unhygienic practices surrounding some of the food vendors (FAO and WHO). A combined effect of innovation and quality is the focus of many governments across the globe. Whiles innovation is a strong backbone for industrialization and economic growth, quality provides a means for sustaining industrial output. Meanwhile, the two concepts sometimes create confusion among industry players. The switch by the Chinese government from industrial output to quality service is an indicator that these two closely related terms are quite different in their application in industrial activities (Compilation and Translation Bureau).

This study was intended to unlock the seeming confusion surrounding proper understanding of TQM and innovation, in respect of the foodservice industry in Ghana. This is to argue that that TQM and innovation are different in terms of theories, concepts, and application. However, one could lead to the other, which goes to emphasize that there is a point of synchronization of the two important concepts in industrial and business practice in recent times. Whereas this might not be the first to study the issue of food quality in Ghana, the objectives of this study are as follows; first, it shows a clear distinction between TQM and innovation in the food service industry. The study is the first to the best of the researcher's knowledge to unlock the teething challenge that confronts growth in the industry amidst the drive for quality. Second, it gives the study a leverage to propose an analytical framework on quality management and innovation in the food industry in Ghana.

The rest of the paper is structured as follows; there is review of relevant literature that follows the introduction. This is followed by the research methodology and a detailed description of the food industry in Ghana, and then 
total quality management and innovation in Ghana, the new quality-innovation paradigm, and finally, conclusion and recommendations.

\section{Literature Review and Related Theories}

Human development, increased civilization and economic growth have led to demand for high quality products and services as well as new and improved products and services. With heightened policies to close the income and inequality gaps, many middle-class people have had an appreciable level of income. This has affected taste and preferences of consumers for goods and services. Many consumers now require value for money goods and services. Coupled with increased knowledge about quality standards of products and the implications on health and income of consumers, organizations are under high pressure to not only offer goods and services but high quality goods and services, which meets the needs and expectations of consumers. In order to satisfy consumers with the right kind of goods and services, organizations implement strategies geared at ensuring satisfaction of customer needs. To achieve these ends, two elements - innovation and total quality management (TQM) - are very important.

\subsection{Total Quality Management: Definition, Theories and Concepts}

Nayab (2011), considered TQM as a philosophy of improving business processes from a holistic approach. TQM can also be defined as a method of improving business effectiveness and flexibilities as a whole. The emphasis is on the essence of proper application to streamline work processes and to monitor and make necessary changes where deviations occur (Nayab, 2011). Adawiyah (2011) on the other hand was of the view that, the role of employees in applying any TQM strategies is highly important. This therefore requires flexibility, skillfulness and employee commitment because quality management requires quality audit to establish and implement necessary strategies. Alternatively, it provides a guide to management on adopting a preventive strategy other than recovery or inspection. As a key, TQM is the pathway to innovation. Total quality management has also been defined as the management process of improving products in an organization. As some have argued, however, TQM leads to production of sophisticated goods (Talib et al. 2011), which could be perceived as innovation. Juran and Gryna (1993), perceived TQM as a system composed of delighted customer, empowered employees, higher revenues and lower costs. The Concept of TQM could be understood as a management philosophy based on continuous improvement of business processes and overall business performance interfaced by selected measurement criteria. To sum it up, total quality management (TQM) increases customer satisfaction by boosting quality. Feigenbaum (1991) defined TQC as an effective system for integrating quality-development, quality-maintenance, and qualityimprovement efforts of various groups in a firm so as to enable marketing, engineering, production, and service at the most economical levels which allow for full customer satisfaction.

Since the inception of the concept of TQM, attention has been given to the customer-focused process aspect which aims for continual improvement of business operations to enhance customer satisfaction. Other aspects of TQM are to improve business processes and manufacturing procedure to yield product quality. Originally, TQM was considered imperative for manufacturing concerns (Investopedia, 2017). However, the concept is being applied by all organizations that aspire to reach different classes of consumers, and advanced markets for goods and services. There are other associated concepts that have been applied by business organizations (Ngambi and Nkemkiafu, 2015), namely concurrent engineering, lean production, Just-In Time (JIT) strategies, Business Process Re-engineering (BPR) and Six Sigma.

Many scholars have contributed to the development and practice of TQM. Different theories have been propounded by these researchers to give impetus to understanding and implementation of TQM principles. Anderson et al. (1994a) emphasized process management practices which were embedded with the qualities of continuous improvement in processes, products and services, with employment fulfillment fully incorporated in the whole chain. Deming (1986) however emphasized the relevance of leadership in the quality management design and implementation. In addition, he considered identification and measurement of selected criteria in the pursuit of continuous improvement very important to the whole quality management process. This led to the development of 14 TQM principles which have been widely applied in organizational management. Juran's perspective was on firm-wide assessment of quality, supplier quality management, undertaking scientific analysis, quality information system, and competitive benchmarking as means of quality improvement. These concepts have $\mathrm{b}$ been summarized in fundamental processes - quality control, quality improvement and quality planning. Feigenbaum (1991) argued that effective quality management consists of four main stages - setting quality standards; appraising conformance to these standards; acting when there are deviations in standards and planning for improvement in these standards. Ishikawa (1985) however propounded the total quality control (TQC) by arguing that quality management comprises quality management, personnel quality and quality of the firm as against just focusing on product. He advanced the concept of employee participation as a major facet to the successful implementation of TQM. He outlined six fundamental principles to explain the concept of TQM. Crosby (1979), rather focused on the quality of organizational management by stressing quality improvement as 
composed of management participation, management responsibility for quality which essentially is moderated by employee recognition, education, and reduction of the cost of quality. Crosby also offered a 14-step program that can guide firms in pursuing quality improvement.

Understanding the import of quality on organizational and industry practice demands a consideration of some models which have been generally accepted the world over as a yardstick for quality measurement and award. As identified by Ghobadian and Woo (1996), these models are embedded with TQM-competitiveness awareness, systematic self-appraisal and market consciousness, need to foster knowledge sharing and dissemination on strategic quality issues and outcomes, creating awareness of determinants of quality excellence and effective distribution, and boosting enterprise continuous improvement practice. The models in view are Deming Prize in Japan, European Quality Award (1994), and the Malcolm Baldrige National Quality Award (1999). These rather focused on two factors: the enablers and the results, where the enablers geared toward TQM implementation and the results encompassed factors such as leadership (organizational), human resources, management, employees education (training) and participation, process management, strategy and policy, information management, customer focus and supplier quality management.

There is convergence on the understanding and right approaches necessary for both enterprise and industrial development to propel economic growth. Most of the research works discussed above point to key issues necessary for quality management. These could be summarized as management quality, employee quality and system quality which will result in quality product for customer satisfaction. The philosophy of TQM is to ensure businesses satisfy the customer, the supplier, and continuously improve the business processes for a desired outcome.

\subsection{Innovation: Definition, Theories and Concepts}

According to Manso (2011), innovation is the exploration of new untested approaches that are likely to fail. He expanded on this view to imply the discovery, through experimentation and learning, of actions that are superior to previously known actions. According to A.T. Kearney (GII Report, 2016) innovation forms from the combination of local expertise and strong global network that elicits deeper understanding of the needs and markets dynamics which ultimately paves the way for continuous flow of ideas. Furthermore, INSEAD (GII Report, 2016), identified innovation as a mechanism essential for sustainable growth." This implies incessant R\&D investments and international cooperation by countries to protect their innovation momentum in the face of low-growth situations. Bröring et. al (2006) however believes innovation is the bringing into existence a product, a service, a process, a new business model, or a management system that provides solution to an existing problem. Schumpeter (1934) in his view argued that innovation is the result of consistent experimentation with new additions of existing resources. For the purpose of this paper, innovation is the driving force behind hi-technology outcomes which has the potential to lead the path to satisfactory and fast-paced industrialization that is necessary for economic growth.

Innovation could be propelled by exploitation efforts or explorative activities. Many researchers have contributed to the development of models for firm performance. Researchers in the field of innovation have made significant input on firm innovativeness and performance, knowledge management, competitive intensity, technology turbulence, market turbulence, formalization and centralization. Notably, Jansen et al., 2006; Darroch, 2005; and Zhou et al., 2005 have researched on various aspects of organization and innovativeness. Aghion and Tirole (1994) however postulated that measuring the outcome of innovative activities is unpredictable. As suggested by Zhang (2012), there is the need for increased and fluid relationship and cooperation between industry and universities (based on national innovation approach), as well as research institutions. Other researchers, particularly Jiang Hui, have defined innovation as an integrated concept involving technology integration, knowledge integration and organization integration. These could however be considered as micro factors essential for innovation. However, there are macro factors that drive innovation.

Globalization opens up an industry for competition and innovation drive (Gunday et al., 2011). It is therefore required of organizations and industries to factor innovation in their business activities if at all they can survive in the global market space (Humphreys et al., 2010). An enabling environment for innovation is the key responsibility of top hierarchy or enterprise management (Ooi et al., 2012). As well as practices geared toward quality. Leavengood et al., (2014) are of the view that there is research gap in respect of how specific quality variables in management practice contribute to an innovation outcome. Also, Guuday et al., 2011 identified unanswerable limitation per empirical research of relationship existing between an innovation outcome and performance of the firm. It is therefore not so clear to researches the extent of the impact of the relationship between quality and innovation. Walder et al., (2015) have therefore suggested a more encompassing empirical work based on the effects of the different innovation variables on enterprise performance. Furthermore, Baregheh et al., (2012) have suggested the need for lots of research on innovation in small and medium-sized enterprises (SMEs).

\section{Methodology}

This study analyzed factors necessary for total quality management through extensive and careful review of literature. The paper utilized the qualitative method by use of in-depth literature analysis. The use of secondary 
data analysis was particularly chosen due to the shortness of time with which this paper was to be submitted. Although the model could not be tested empirically to assess its strength and weaknesses, the availability of secondary data helped to form the theoretical basis upon which the model was proposed. In the view of the researcher, the proposed model will be suitable for assessing and measuring food quality in Ghana, especially using the three-dimensional facets approach.

Relevant literature in the form of reports, articles, online write ups, budget statements, and conference and working paper were obtained from sources such as the FAO website, Ministry of Finance and Economic Planning, Ghana, Food and Drugs Authority, various journals. This was to ensure underpinning theories, concepts and models are well understood by the researcher. Extant literature was also extracted from more economically developed countries and less economically developed countries. Also, literature took into consideration quality publication spanning several years due to underlining theories, concepts and conventions.

\section{An Overview of the Economy of Ghana}

Economic growth in Ghana has been largely attributed to the incomparable role played by the agriculture sector. In Ghana, the service industry which includes the restaurant and hotels sub-sector, contributed 54.6\% to GDP in 2015, 56.8\% in 2016 and 55.9\% in 2017 (Ministry of Finance and Economic Planning, 2018). Agriculture contributed almost $35 \%$ to the Ghanaian economy in 2007, with similar trends in other parts of Africa, but the sector suffers from lack of adequate infrastructure and highly skilled human labor force, and inappropriate technology to enhance operations and outcomes. Within the same time frame, 2007, the industrial sector which comprises mining and quarrying, manufacturing, and construction sub-sectors, contributed $24.6 \%$. The main challenge that confronted this sector was inadequate power supply and industrial energy generation (falling electricity output), increased taxes and dumping. The challenges afore mentioned are coupled with poor and inadequate infrastructure in terms of transportation system. Similarly, the service sector contributed close to $30 \%$ of GDP with contributions emanating from finance and insurance and tourism.

In the terminology of Ghanaian planners, the country is ready to move from the economics of reconstruction and rehabilitation to the economics of accelerated growth (National Development Planning Commission, 2005). This implies diversification away from the cocoa-gold-timber structure towards industrialization, technology and higher productivity, all with a view to achieving middle-income status by 2020.

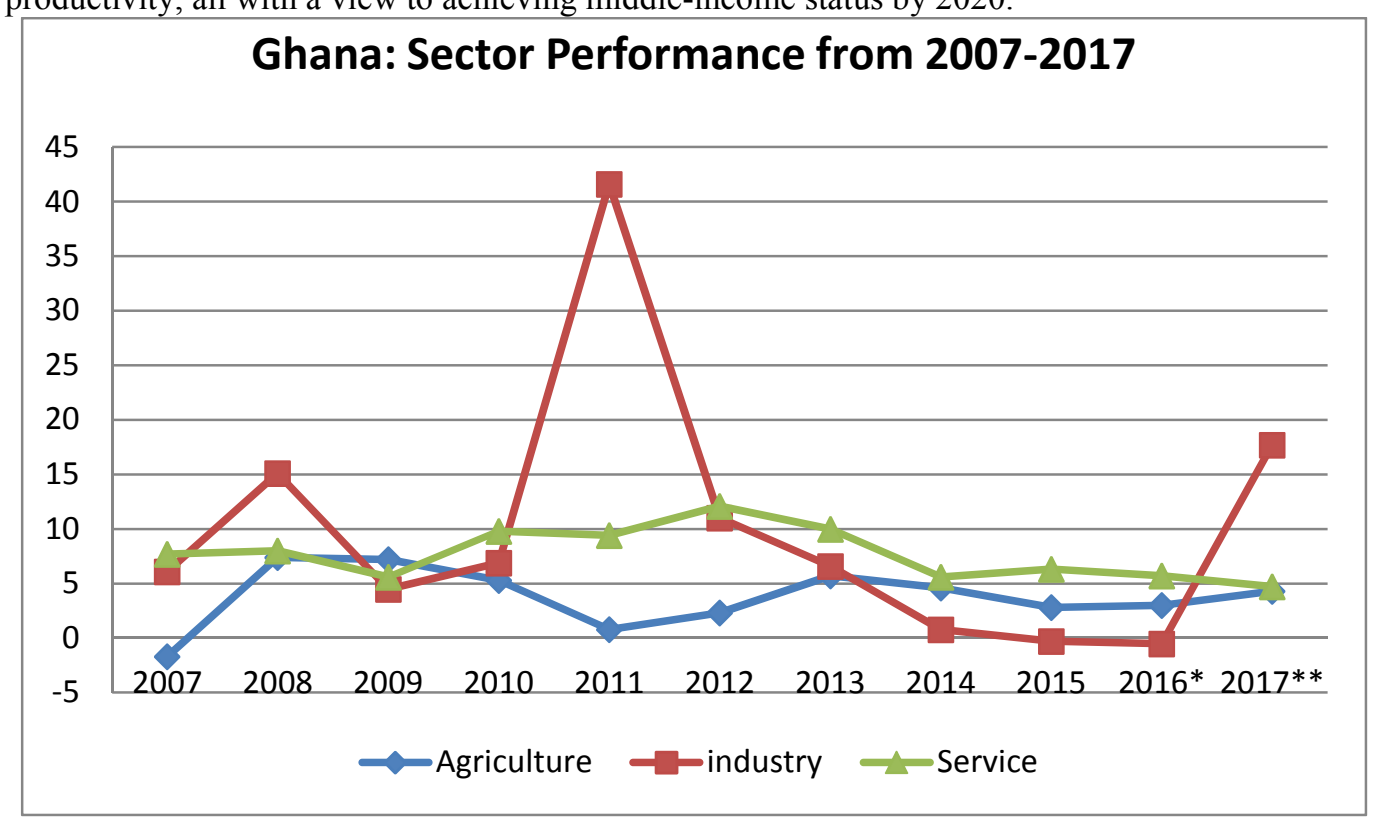

Fig. 1.Ghana Sector Analysis

Source: Various Issues, Budget Statement of the Republic of Ghana

Figure 1 indicates the performance of various sectors from 2007-2017. There has been quite consistent overall sector output over the period. The agriculture and service sectors have achieved quite consistent growth and output pattern. It could be argued that the two sectors have not grown beyond opportunities experienced in the economy over the period. This however requires government action to boost total factor productivity of the two sectors, considering the enormity of their inherent potentials. The industry sector has shown quite inconsistent output and growth patterns. For instance, the seemingly unusual jump of industry sector output in 2011 was as a result of the commencement of oil extraction in commercial quantities. The sector is yet to realize the full impact of FDI inflow to ensure this consistent growth trend. 


\section{Transition from Traditional Food Service to Advanced Food Service}

\subsection{Overview of the Service Industry}

Traditionally, the food industry has been an integral part of the service industry. Generally, a service industry could be identified by factors such as intangibility, variableness, inseparability, heterogeneity and measure difficulty. Inseparability is a situation which poses a challenge for some areas of service because the consumer is usually part of the process. The key issues involved in total quality management and innovation can be better understood by proper identification of the food industry. The food industry here implies the manufacturing sub-industry, particularly, restaurant enterprises, canteens, fast food joints and catering houses. The industry could be classified either as traditional food industry and semi-modern industry or modern (advanced) food industry. For the purposes of this paper, industry refers to the foodservice sub-industry (sector) of the food industry. Further, the focus is on how food is manufactured (out of home eating) in Ghana.

The food industry has for a long time been part of the traditional service industry, thereby, not considered as a manufacturing concern. However, the industry has metamorphosed into an advanced-manufacturing concern with strong service orientation. The figure below shows the transition of the foodservice industry from traditional service industry to modern and manufacturing industry.

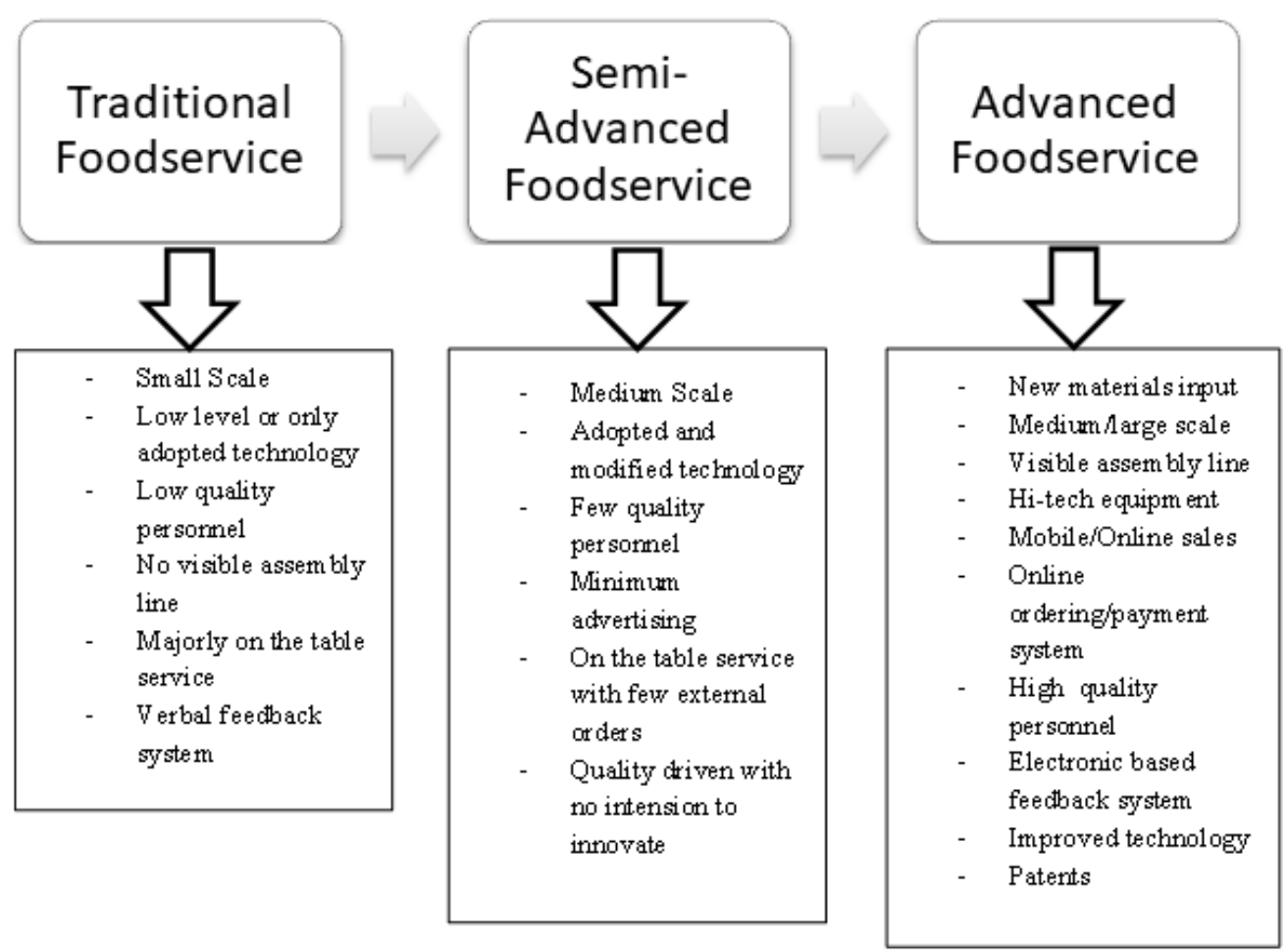

Fig. 2. Food service metamorphosis chart

\subsection{The Food Industry in Ghana}

The government of Ghana has embarked on numerous projects to boost, improve and sustain food production in Ghana. This has been underpinned by food security programs through loans and grants from development partners such as Japan and Canada, which gave various sums to the government of Ghana in 2010 for such purposes. Although these programs have targeted macro level food production, their impact on the food value chain cannot be over-emphasized. Ababio et al. (2013) noted that food chain exists in the form of agricultural production and harvesting, holding and storing of raw materials, food manufacturing, transportation and distribution, retailing, food service and food preparation in various homes. Cronin Jr. et al (2000) found that quality, value and customer satisfaction are means by which behavioral intentions could be directed.

The Ghanaian economy is stratified into three key sectors, agriculture, industry and service. In Ghana, the food industry however cuts across all three sectors of the economy. It could be observed that although overall contribution has been positive over the period, there has been negative growth in some years. Whiles hotels and restaurants belong to service sector of the economy; manufacturing belongs to the industry sector of the economy as could be seen in Figure 2. There is an appreciable growth of the service sector as represented by hotels and restaurants from 2015 to 2017 by more than 1\% on average (Ministry of Finance and Economic Planning, 2018). 


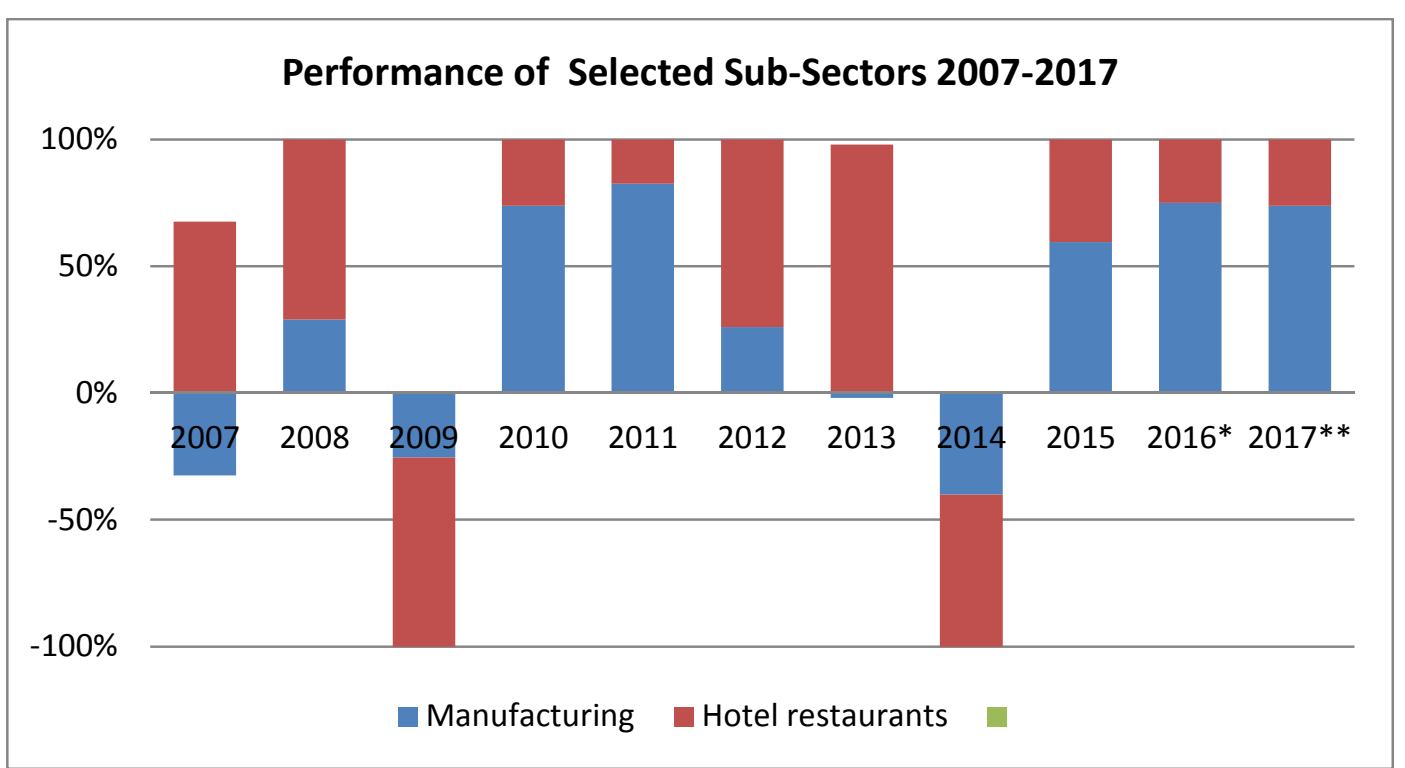

Fig. 3: Manufacturing and hotel \& restaurant GDP (2007-2017)

Source: Various issues, budget statement of the Republic of Ghana

Figure 3 however shows the contributions of manufacturing, and hotel and restaurant sub-industries from the period 2007 to 2017. By and large, the contributions of these two sub-sectors have not been too impressive but appreciable, although output declined at some points, 2007, 2009 and 2014. This calls into question the effect of transforming the foodservice sub-industry from a service sector to an industrial sector with service characteristics. This requires capital injection, new technology, and high skilled labor, among others.

The Trade Policy of Ghana from January 2006-December 2010 included the need to develop measures with clear and sufficient rules on consumer protection of which food safety systems play critical role. Undoubtedly, the food industry faces several challenges confronting the food industry in Ghana. The industry in some countries have received impetus from government and other organizations to boost their ability to design, implement and maintain quality standards or controls over the entire food value chain. In spite of the seeming policies and research considerations given to the industry, the traditional aspect of the food industry faces critical challenges that have direct impact on activities of human life. These challenges are however multi-faceted, but they can be broadly grouped into external and internal challenges. Internal challenges comprise management incapability, lack of qualified personnel and inadequate financial resources. On the other hand, external challenges involve inappropriate and targeted policies, lack of appropriate supervision by relevant agencies and amateur consumer groups. However, FESDEP II (2007) identified human resource and managerial skills; natural resource management; technology development and dissemination; infrastructure; market access; food insecurity and irrigation development and management as broad challenges facing the agriculture (food industry inclusive) in Ghana. Aside these factors, the industry is unable to innovate as a result of low perceptivity to technological change. Continuous reliance on traditional methods has not in any way produced better foodservices and innovation.

\subsection{New Paradigm on Service Industry}

Most researchers have espoused some agreed principles such as managerial and organizational commitment, customer focus, benchmarking, supplier relationship and continuous improvement to assess quality management in organizations. Although the focus is on the entire organizational process, these are not adequate considering the critical nature of the products and services in question. The role of government in promoting quality management in enterprise and industrial management should be viewed as highly essential in modeling a quality management system in Ghana. Having studied the short-coming in previous TQM models, the dynamic quality model (DQM), a version of TQM, has been proposed, which has wider variable scope to enhance deep understanding TQM from national perspective and to ensure an effective way of measuring and accounting for quality management in Ghana. The DQM framework above implies that, quality management in the food industry in Ghana can be achieved by the culmination of the efforts of the organizations (enterprises), the market and government. In other words, DQM supposes that an effective quality management is a function of organizational factors, market conditions and government interventions. 
Table 1: DQM Variables

\begin{tabular}{|c|c|}
\hline Key Factors & Variables \\
\hline \multirow{5}{*}{$\begin{array}{l}\text { Industry Based } \\
\text { Factors } \\
\text { (Organizational) }\end{array}$} & Management Competence \\
\hline & \begin{tabular}{ll}
\multicolumn{2}{l}{ Capacity } \\
- & Financial \\
$\bullet$ & Logistics \\
\end{tabular} \\
\hline & $\begin{array}{r}\text { Ownership Structure } \\
\quad \quad \text { Scale effect } \\
\end{array}$ \\
\hline & $\begin{array}{l}\text { Employee Quality } \\
\text { - Years of education } \\
\text { - Level of education } \\
\text { - Years of experience in the industry or related field }\end{array}$ \\
\hline & Number \& Value of Training programs \\
\hline $\begin{array}{l}\text { Market } \quad \text { Based } \\
\text { Factors }\end{array}$ & $\begin{array}{l}\text { - Structure of the Market } \\
\text { - Customer feedback systems } \\
\text { - Participation in Food shows, exhibitions and competitions } \\
\text { - Awards System } \\
\text { - Traceability System } \\
\text { - Direct or indirect role of consumer associations and civil society groups }\end{array}$ \\
\hline $\begin{array}{l}\text { Government } \\
\text { Factors }\end{array}$ & $\begin{array}{ll}- & \text { Policies \& programs } \\
\text { - } & \text { Regulations } \\
\text { - } & \text { Quality of Human resource } \\
\text { - } & \text { Corruption Reduction } \\
\text { - } & \text { Supervision \& Surveillance } \\
\text { - } & \text { Special quality incentives } \\
\end{array}$ \\
\hline
\end{tabular}

Industry side factors are essential for ensuring that organizations and industry measures up the task and have codified system of ensuring and measuring quality. Industry must set the bench mark for ensuring practitioners abide by a quality management system. Market can generate the push that will ensure industry and its operators practice needed quality management systems. For is an essential element for life and its sustenance. As such, government should use its systems and mechanism to ensure compliance to existing laws, regulations, policies and programs, whiles delivering an effective approach to make these self-regulatory.

\section{Food Quality and Innovation in Ghana}

Some researchers are of the view that using traceability system can facilitate the attainment of food quality, for example, Golan et. al., (2004); Sansawat and Muliyil, (2012) observed that food quality management exists in various forms: BRC, ISO 22000, HACCP, GMP, SQF, FSSC 22000, IFIS and Global GAP. Particularly, the implementation of HACCP across countries has shifted food quality responsibility from regulators to industry players. Whiles governments have been advised to recognize the HACCP concept as a fundamental tool for managing food quality FAO/WHO. However, the role of government cannot be over emphasized as it is required to implement the Codex Alimentarius Commission standards. The FAO/WHO identified some variables that should be inputted in the food quality standards: Food Law and Regulations, Food control Management, Inspection services, laboratory services, and information, education, communication and training. As has been stated earlier, TQM focuses on promoting consumer wellbeing and quality taste. Food quality has socio-economic implications as push or pulls factors. The Development Policy Department (2014) identified poor sanitation and hygiene as environmental factors and diet quality as some of the factors to be considered in designing a food policy, as well as, nutritious foods and low price. Therefore, ensuring food quality requires undertaking necessary steps to certify food traceability system to help eliminate problems of food contamination, allergies and unhealthy genetically modified food. The aim of food quality, among others, is risk minimization throughout the food value chain.

The Ghana standards Authority and Food and Drugs Authority are two entities with regulatory powers to ensure quality in delivery of products (food inclusive) in Ghana. The FDA for instance exist to implement the appropriate regulatory measures to achieve the highest standards of safety, efficacy, and quality for all food - locally manufactured, imported, exported, distributed, sold, or used, to ensure the protection of the consumer as envisaged by the law regulating food and drugs in Ghana. The FDA through it Food Inspectorate division ensures food safety and quality. The Authority also conducts Food Industrial Support Services by conducting training on good manufacturing practices (GMP), Hazard Analysis Critical Control Point (HACCP) and ISO 22000 food safety management system. Educational institutions, particularly universities and polytechnics, also have programs aimed at promoting quality food management in Ghana. The challenge however, is the low number of high skilled manpower employed in the hotel, catering and restaurant sub-industry in Ghana. This could 
be attributed to cost and personnel availability factors.

The essence of innovation in Ghana, however, encompasses individual enterprises, industries, and the general economy (Boehlje, Bröring, and Roucan-Kane; 2009). Suwandej (2015) found the following seven factors necessary for quality management among public sector organizations in Thailand, namely, leadership, training, organizational structure, communication, incentives, measurements and evaluation and teamwork. According to Ababio et al. (2013), the application of traceability system in Ghana is very poor if not none existent. Kmieciak, Michna and Meczynska (2012), found a positive relationship between SME innovative activities and technological turbulence, innovation climate, investments in innovation and use of internal ICT. It was also established that innovation activity and IT knowledge were positively related with subjective firm performance. Mckinsey proposed the 7-S technique of total quality management (TQM). This technique seems to have widespread implication on organizational management with focus on strategy, structure, system, staff, skill, style and stakeholder (shared value). There are other propositions on the principles of quality techniques. These principles are innovation in all areas including training and providing resources, "zero-defect" philosophy and continuous improvement. Although policy is an important input for innovation drive, it is not a necessary condition as some forms of policy may yield negative effect (Bas and Paunov, 2018). Acemoglu and Robinson (2013) also argued that an underpinning theory of policy as a solution of market failure hinges on the awareness of externalities, public goods, monopoly and imperfect competition that distorts the social welfare. However, although earlier researches had recognized the appropriateness of policy in consonance with context, the sort of intervention and informational abrasions and politics was excluded from the model.

Table 2: Contribution of the Food Industry in Europe

\begin{tabular}{|l|l|}
\hline Category & Contribution \\
\hline Turnover & 965 billion euro \\
\hline Employment & 4.4 million people \\
\hline SMEs & Turnover: $48.7 \%$ (food and drinks) and Employment: $63.0 \%$ (food and drink) \\
\hline
\end{tabular}

The EU: Source: CIAA Data and Trends, 2009

\subsection{A New Paradigm on TQM: Conceptual Framework}

This section will elaborate on the constructs of the Dynamic Quality Model. The dimensions of the DQM can be viewed from endogenous factors and exogenous factors. Endogenous factors tare those that do not form part of the main model or could be eliminated from the model with minimum or no effect on the model and its implication. Two elements have been identified in this category - research and development (R\&D), Internationalization (globalization). R\&D serves a multi-purpose function in industry and enterprise development. In a quality model of this nature, $R \& D$ is necessary to ensure the enterprise has the right kind of information to improve its processes, procedures and products. However, R\&D is key ingredient in an innovative outcome. As a result of international trade, Ghana is opened for doing business across boundaries. It must therefore ensure to implement relevant protocols agreed to by international treaties. Although this might be more targeted at the key constructs of this framework are

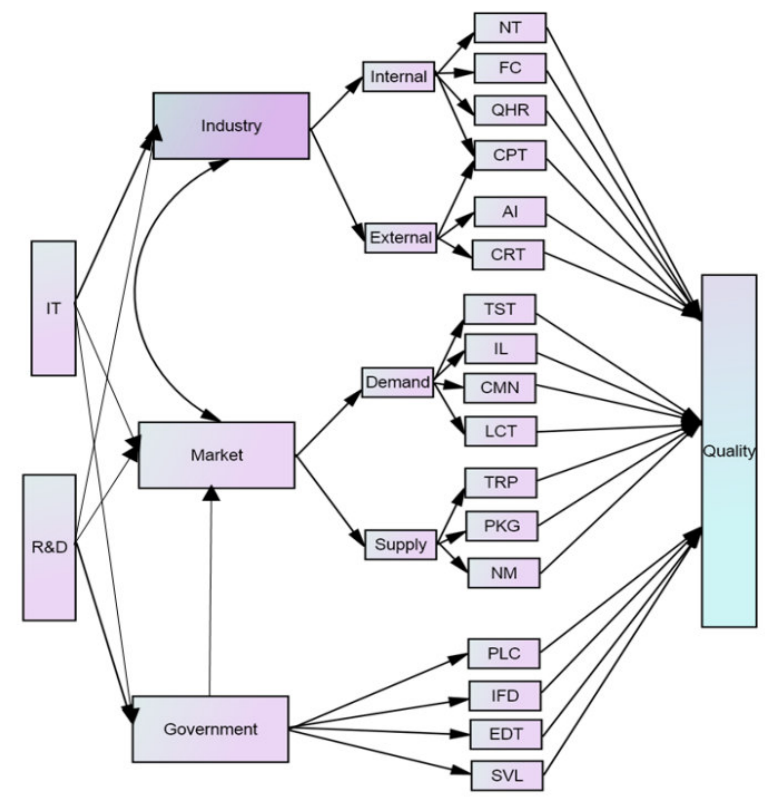

Fig. 4. Dynamic Quality Model 


\subsubsection{Endogenous Factors}

The first factor in this category is international trade, as denoted by IT. The demand for quality is not only a local issue. Ghana is a country that is opened up for cross border trade. As such, it is imperative to ensure food quality as this will give the country a much global outlook. Bad food quality has the potential to stifle international activities and will give bad image to the government and its people. Ghana has been hosting a number of international conferences, as such, the country is expected by to deliver safe foods. International trade also affects the conduct and performance of the food industry; market conditions and government programs.

Another important factor that has the high potential to boost operations of the food industry is research and development, denoted by R\&D. This can be industry (enterprise) driven, market driven or government driven. For example, activities of the food and drugs authority give government adequate firsthand information on policy and program directions. Some industries also have a quality research system that ensures that enough information is obtained to implement strategic changes that will advance the industry. This calls for congruence between industry, research and academic institutions to create a platform for continuous research and improvement and proper implementation of new ideas to enhance quality attainment.

\subsubsection{Exogenous Factors}

Industry-based factors are bi-functional. They can be explained from two perspectives: internal and external. Internal factors comprise new technologies, financial capacity, quality personnel and competition. Quality comes at a cost. This requires acquiring new technologies and gadgets, hiring of additional staff or highly skilled staff and/or acquiring new facilities to facilitate business activities. Better technology leads to food quality. Availability investment opportunities and access to financial credit are essential to this course. The scale of the foodservice industry in LEDCs impedes their ability to acquire advanced technology, which is a necessity for innovation and food quality. External factors are made of competition, demands from allied industries and contracts. Competitions have both intra and inter industry function to drive quality output. Within an industry, enterprise performances, activities and operations are measured by industry bench mark. This in most cases creates some form of competition among industry players in an attempt to measure up with the standards. This is further backed up by industry awards. Allied industries also serve a very unique role in enhancing quality achievement. Certain industries which require services of the food industry usually have their own quality standards. This puts pressure on food industry players to deliver to such standards. Contract, as in the case of allied industries is a quality enhancing tool. Some organizations in the food industry avoid such contracts because of their inability to deliver to standards. Such contracts may require on premises inspection, use of certain equipment, materials and a certain level of human resource to handle food preparation.

Market has direct and strong influence on the quality outcomes of industry activities. This is stratified into demand side and supply side factors. Demand side factors are taste, income level, consumer and location. Consumer taste and preferences are essential to food preparation, serving and preservation. Food and food products from different enterprises have been accustomed to a certain taste. Once this taste is not achieved, customers are likely to raise concerns over such differences. Income level increases the bargaining and purchasing power of consumers. Once the right quality is not given, consumers are most likely to change their food suppliers. Additionally, high end consumers can enforce certain quality changes because they contribute substantially to the financial and business success of such enterprises. The number of consumers that patronize the food industry is increasing due to changes in lifestyle, rising income levels and job location. This is a tool that can be used to demand and promote quality services from the food service industry. In some countries, consumer associations and consumer protection agencies have continued to play critical roles in food service management. Supply side issues are transport, packaging and new materials. One of the key ingredients to food quality is the raw material. This requires an effective delivery system achieved through traceability. Raw material handling also poses some form of challenge for food quality. This requires effective transport system that can guarantee food safety. Packaging is another challenging factor for the foodservice industry in Ghana. Some food vendors handle packaging issues so poorly thereby exposing food to bacterial and fungus infections. There is need for suppliers to adopt new packaging materials that could be supplied to foodservice practitioners.

Governments of LEDCs are being demanded to accept responsibility for qualities issues regarding food delivery due to consumers' keen interest in all processes relating to food delivery and service (WHO and FAO). The role of the government encompasses promulgation of laws, surveillance, monitoring and enforcement. "...a mandatory regulatory activity of enforcement by national or local authorities to provide consumer protection and ensure that all foods during production, handling, consumption; conform to safety and quality requirements; and are honestly and accurately labeled as prescribed" For example, cholera has been estimated to be the cause of 100,000 deaths annually. This is a foodborne disease contracted through eating and drinking infested food. Although the continent has suffered from cholera outbreak since the mid-1980s, data shows that in $1999,80 \%$ of cholera cases in the world occurred in Africa (FDA/FSMD-GL-FBD/2014/01).

The factors that lead to quality in the food industry as driven by government are industrial or targeted policies and programs, infrastructure development, education and surveillance. In developing countries, most of the 
policies and programs are rather designed and/or implemented as a mitigation measure, other than precautionary measure. Government policies and programs are mostly reactionary other being 'proactionary'. The government therefore needs proactive and pragmatic research and surveillance to solicit appropriate information for timely policy action. Policy plays key role in quality design, implementation and practices. Policies must provide support in the form of skills training, quality management and financial sponsorships, as well as trade dialogue and exhibition. Infrastructure development propels easy compliance with policy direction.

Specialized fields of learning bring in specialized skills that are required by industry to help achieve the broader objective of quality in the food industry. Additionally, more people should be encouraged to apply for study in the fields of food science and food management. Young scholars should also be incentivized to undertake more research in this field. Surveillance is an essential factor in the government side factors to quality achievement. In Ghana, the Food and Drugs Authority has the mandate to ensure food quality, among others, is achieved. An effective tool to attain this goal is supervision. This must be a continuous activity to ensure industry operators are in tune with the intention of the government. In situations where policies and regulations are seriously flouted, prosecution must follow to deter players in the industry from breaching the code of both legal and social contract to deliver healthy, safer and quality food service. Thus, the unit responsible must be well resourced financially and must rely on the services of highly qualified personnel. Another essence of conducting surveillance is the reduction in moral hazard and information asymmetry.

Governments have the mechanisms to design, implement and enforce compliance to laws and regulations. Among the mechanism used in Ghana is institutional role. One of the institutions tasked to ensure the development of technology and maintenance of standards in Ghana are the Ghana Standards Board (GSB), and the Food and Drugs Board (FDB). By legal mandate, the FDB is responsible for regulating the manufacture of food products, pharmaceuticals, cosmetics and chemicals. This implies the registration of all food products before they are made available to consumers. The Board conducts unannounced clinical trials and testing of food and pharmaceutical products. The Ghana Standards Board is responsible for the overall management and coordination of standardization issues in Ghana. It deals with quality standards for foods, metals, pharmaceuticals and other products. It conducts quality tests and issues quality assurance certificates. Unfortunately, some public and private institutions are oblivious of the various quality standards and the importance of meeting standards in order to be competitive in international markets. The main institutional actors in the national system of innovation however, are universities, public R\&D institutes, policy-making bodies and government in general, private enterprises, financial institutions such as commercial banks, and technology support agencies.

\subsection{A New Paradigm on Innovation: Conceptual Framework}

Cooperative units, "industry convergence" and "inter-industry segments" have been associated with high innovation beyond a singular industry (Bröring, Cloutier and Leker, 2006). Psomas, Kafetzopoulos, and Gotzamani, (2018) did not factor into their model, the influence of government either on the quality side or innovation side. In his model however, quality practices of top management and process quality directly contribute to product and process innovation. Kumar and Sharma however noted that profit increase requires an integration of TQM and innovation, Zapata-Cantu (2007) et al., on the other hand consider innovation as the main contributing factor to company performance. Mauch (2010), suggested that achieving quality demands balancing objective, procedure and policy against merely seeking the benefits of a quality outcome. From an organizational point of view, quality should be incorporated into the organizational chart in terms of the reporting channel. Marietta, Barra and Zotti (2017) considered academic-based knowledge had influenced industrial innovation since 1988. Other researches recognize the role of national mechanism in disseminating knowledge to the food and drink industries of MEDCs as noted by Rama (1999, 2008)

Innovation is composed of three key elements: drivers, process and outcome. These are the main ingredients that make up innovation. Whiles TQM might not directly affect productivity, innovation almost always results in increased profit and economic growth Karantininis, Sauer and Furtan (2009). Invariably, TQM is input oriented whiles innovation is both input and output oriented. According to Boehlje, Bröring and Roucan-Kane (2009), process driven innovation has the potential to enrich quality and advance process. Innovative activities can be perceived from three perspectives, namely, innovation drivers, innovation processes and innovation outcomes. Innovation drivers could be as a result of push or pull factors and/or explorative or exploitative factors. Some scholars have considered innovation drivers in terms of "market pull", "technology push" and regulation (Mowery and Rosenberg, 1979; Boehlje, Bröring, and Roucan-Kane, 2009). An innovation begets another innovation. Thus, one innovation serves as tool or the source of another innovation. This phenomenon could be described as innovation cycle. In addition, this kind of innovation effect becomes a driver for the next move. The literature on industrial organization, including Roberts and Weitz-man (1981), Jensen (1982), Battacharya, Chatterjee, and Samuelson (1986), and Moscarini and Smith (2001), relied extensively on bandit problem and related models of learning through experimentation to study the innovation process. Papers on growth theory, such as Jovanovic and Rob (1990), Jovanovic and Nyarko (1996), and Aghion (2002), developed detailed models of innovation as the 
result of learning from the experience of others. Boehlje, Bröring, and Roucan-Kane (2009) stated that the innovation analytical framework must be adoptable considering changes in time and uncertainty factors. Generally, innovation has four main outcomes - new or improved process, new or improved product, new or improved service, and new actors Ollila, and Yström, (2016).

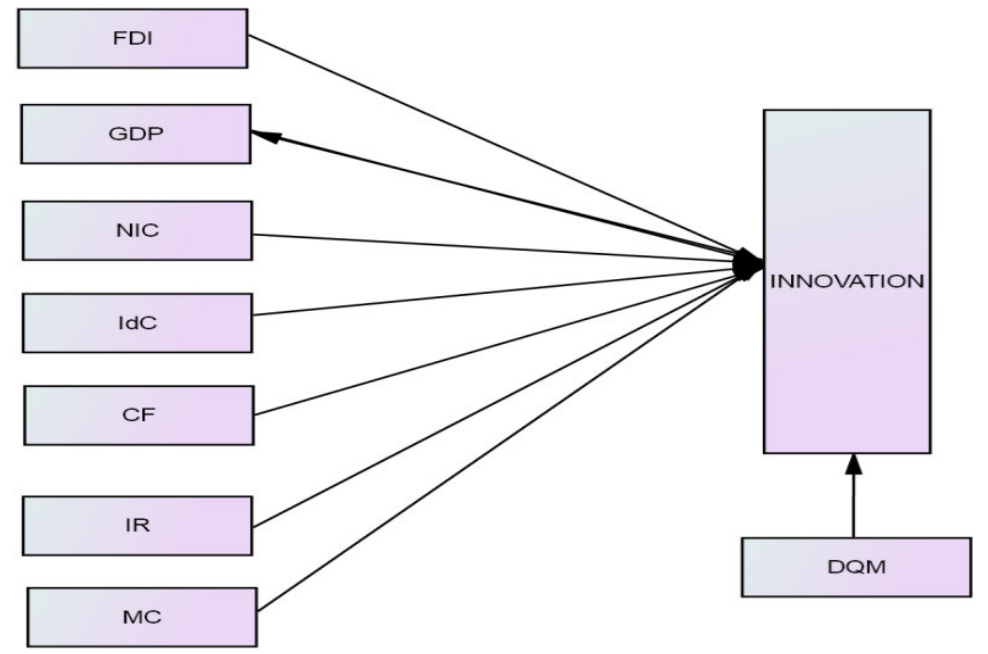

Figure 4: Sustainable Innovation Model

The model has been so named due to the inclusion of the DQM. Sustainable innovation focuses on two factors: ability to continue innovating due to acceptability of innovative outcomes and the dependability of the innovation due to its quality so as to reduce social and capital costs, whiles increasing profitability and social benefits to consumers of such innovation. As noted by Lamptey (2009), a strategic planning process embedded with quality management also forms a creative approach to achieving innovation. Also, Eckes (2001) was of the view that quality programs should be used to increase business performance through reduction of practices that are not useful and thereby creating "forced innovation". These have shown that quality and innovation are closely linked, hence, the term "sustainable innovation" justified by the inclusion of DQM in the model. When quality is embedded in innovation, it leads to quality and sustainable innovation.

\subsection{Challenges of the New TQM and Innovation Conceptual Models}

The Global Innovation Index (2016) highlighted sustainability of R \& D investment in Africa is highly essential. Out of 128 countries that were measured, Ghana ranked 102th in terms of innovations in the World. It ranks $10^{\text {th }}$ among African countries that were assessed in the same survey. The need for innovation and quality improvement is not negotiable. Ghana's political stability has made it an envy of many investors in sub-sahara Africa. Ghana has consistently been home to many FDI destinations, international conferences and tournaments. This is juxtaposed to the economic growth potential, thereby, raising the standard of living of many people, especially the middle class. The quest for innovation is on the basis of the impact of innovation on economic growth; market availability (growing number of middle class, increasing disposable income of middle class, influx of expatriates and hosting of international events); changing lifestyles (need for new and improved products and services) and sustainability issues (policy and supervision)

The challenges confronting the new frameworks are financing. It requires huge cost to register patents that are obtained through an innovative outcome. Quality and innovation also require time to mature. This can pose many problems for SMEs in terms of personnel and financing. Closely associated to this challenge is the risks of failure and copy of a patent when an enterprise has not fully achieved its benefits. Another risk is the failure of the market to accept the outcomes of innovative activities - new product, new processes, etc.

The social benefit of TQM is the utility derived from improved product and services to consumers. Particularly in the food industry, it can be seen as implicit and explicit benefits. Implicit benefit is the level of satisfaction consumers can derive from consuming quality food. This could be measured in customer feedback systems. On the other hand, explicit benefit implies savings made as a result of consuming good food. Consumers and governments make savings as a result of people not consuming contaminated food.

Social cost is however more explicit in nature. This is the cost that accrues to individuals and the society for consuming polluted food. As has been a cyclical issue in Ghana, cholera outbreak has cost implications for the government, families, social groups and the individuals. Unfortunately, lives have been lost as a result of eating unclean food. Ultimately, social cost is higher than private cost. 
Table 3: Cholera cases, deaths, and case fatality rate reported to WHO by region (World, Africa, Asia, Latin America), 1960-2005

\begin{tabular}{|ll|c|c|c|c|c|}
\hline World Bloc & $1960-1969$ & $1970-1979$ & $1980-1989$ & $1990-1999$ & $2000-2005$ \\
\hline $\begin{array}{l}\text { Sub-Saharan Africa \% of } \\
\text { world reported cases }\end{array}$ & 19 & $\begin{array}{c}19.7 \% \\
(176,849)\end{array}$ & $\begin{array}{c}59.4 \% \\
(298,295)\end{array}$ & $\begin{array}{c}42.2 \% \\
(1,240,277)\end{array}$ & $\begin{array}{c}93.9 \% \\
(758,866)\end{array}$ \\
\hline $\begin{array}{l}\text { Sub-Saharan Africa \% of } \\
\text { world reported deaths }\end{array}$ & & $\begin{array}{c}22.4 \% \\
(18,398)\end{array}$ & $\begin{array}{c}81.8 \% \\
(22,298)\end{array}$ & $\begin{array}{c}77.1 \% \\
(65,914)\end{array}$ & $\begin{array}{c}97.2 \% \\
(18,196)\end{array}$ \\
\hline
\end{tabular}

Source: The American Journal of Tropical Medicine and Hygiene. (2007) 77, 705. Available at: https://doi.org/10.4269/ajitmh.2007.77.705

Table 4: Cholera cases, deaths, and case fatality rate reported to WHO by region (World, Africa, Asia, Latin America), 2000-2005

\begin{tabular}{|l|c|c|c|c|c|c|}
\hline World Bloc & 2000 & 2001 & 2002 & 2003 & 2004 & 2005 \\
\hline Sub-Saharan Africa \% of & $86.8 \%$ & $94.1 \%$ & $96.9 \%$ & $96.9 \%$ & $94.3 \%$ & $94.8 \%$ \\
world reported cases & $(118,932)$ & $(173,359)$ & $(137,866)$ & $(108,067)$ & $(95560)$ & $(125,082)$ \\
\hline Sub-Saharan Africa \% of & $93.9 \%$ & $94.9 \%$ & $99.7 \%$ & $99.5 \%$ & $99.4 \%$ & $98.2 \%$ \\
world reported deaths & $(2,590)$ & $(2,590)$ & $(1,884)$ & $(1,884)$ & $(2331)$ & $(2230)$ \\
\hline
\end{tabular}

Source: The American Journal of Tropical Medicine and Hygiene. (2007) 77, 705. Available at: https://doi.org/10.4269/ajitmh.2007.77.705

The data in tables 3 and 4 justify the inclusion of government as a key component of the proposed model. Governments have the resources to design, implement and enforce quality standards. This is task is beyond the capability of civil society and consumers. The problem can however be minimized by ensuring strict compliance of laws and regulations by food service organizations. Regular supervision of the materials, equipment, disposal system and premises of food service enterprises is essential to maintaining low social cost of eating infested food.

\section{Conclusion and Recommendations}

\subsection{Conclusion}

Food is very important to human life. The Chinese adage "Si mi wei tian" emphasizes the importance of food to humans. However, due to changes in weather patterns, soil composition and human behavior, many dishes fall short of the desired quality in Ghana. Also, the foodservice industry is lagging behind in launching new and improved products that increases it competitiveness. Globalization, international trade and other changes in lifestyle patterns are un-debatably begging on the need for quality and new way of doing business, as well as products. With increased social status, level of disposable income and right perception about health, many consumers now desire quality foods. To obtain quality food, restaurants, food joints, canteen and catering houses must ensure quality of food is incorporated in their organizational management. This requires competent management, quality staff, quality internal standards and procedures, quality raw material and suppliers, and increased financial capacity. Additionally, the role of government is highly essential obviously due to the importance of food to human life. The Government of Ghana needs to design appropriate policies that will promote quality food practices throughout the food value chain. Similarly, government and government agencies must ensure effective implementation of quality standards through surveillance and close supervision, whiles preferring serious sanctions against any form of breach to reduce both social and private costs. The government can also enhance compliance by conducting or arranging training programs to ensure industry players are up to speed with current trends in quality management.

This paper was designed to analyze the total quality management and innovative capabilities of the food industry in Ghana from three multi-dimensional perspectives - industry, market and government. To this end, the paper has put forward the multi-dimensional TQM framework termed dynamic quality model. Also, an innovation framework, sustainable innovation framework has been put forward to help industry players to understand the encompassing nature of innovation. This framework is embrace and challenges business practice across the food service industry. This is considered to be essential for both industrial and business development in Ghana, thereby, harnessing their competitiveness.

The main theoretical contribution of the paper is the design of a comprehensive conceptual model (the dynamic quality model) that focuses on three dimensions. The dynamic model takes into account different interrelated facets and changes in social, business and political dynamics with reference to progress of time. There is the need for further research on this subject, considering the limitation of time it took to carry out this work and the inability of the researcher to conduct empirical analysis to test the efficacy of the variables in the framework.

\subsection{Recommendations}

Whether or not the food service industry in Ghana should focus on quality management or innovation drive partly depends on the business model in practice and the industrial strategic goals and policies of the government. With 
an economic growth in focus, the government should enact policies that would drive innovation. This could be achieved by (i) linking industry to academic and research institutions, (ii) embarking on training for industry operators, (iii) funding support through tax cuts for recruitment of qualified personnel and investment in new technology, as well as, training and development (iv) helping the industry to develop new markets for goods and services, (v) creating a platform for joint venture with both local and foreign partners and (vi) promoting national innovation competition and awards for the food industry.

An indirect approach to achieving innovation in the food service industry in Ghana is to use the total quality approach. First, it requires government to strengthen its quality drive and surveillance by ensuring policies are well focused on intended outcomes. Second, the government must ensure that all participants in the industry are registered to ensure smooth and effective implementation of policies and programs. Finally, the government should continue to support the industry by building closer ties with owners and managers of the firm, and the industry at large. .

Nonetheless, industry also has a role to play in the whole quality and innovation equation. First, industry should make innovation a priority and this must be backed by company strategy and business models. Second, company must have in mind their social contract with consumers so as to ensure that dishes follow the best standards. Third, industry-based exhibition is highly necessary for knowledge and ideas sharing. Forth, industry must also develop a supply chain system that has quality embedded in it. Fifth, participants in the industry must also engage in effective advertising, especially when new products are introduced, and conduct frequent feedback to ensure goods and services meets the quality demands.

\section{References}

Ababio, P. F., Adi, D. D. \& Commey, V. (2013). Traceability: Availability and Efficiency among Food Industries in Ghana. http://dx.doi.org/10.4236/fns.2013.42018. http://www.scirp.org/journal/fns

Acemoglu, D. \& Robinson, J. A. (2013). Economics Versus Politics: Pitfalls of Policy Advice. Journal of Economic Perspective - Volume 27, Number 2 - Spring 2013, Pages 173-192.

Adawiyah, W. R. (2011). The Relationship Between Soft TQM and Work Related Outcome: The Moderating Impact of Spirituality at the Workplace. Thesis Submitted to the Othman Yeop Abdullah Graduate School of Business, Universiti Utara Malaysia, in Fulfillment of the Requirement for the Degree of Doctor of Philosophy

Addae-Korankye, A. (2013). Total Quality Management (TQM): A Source of Competitive Advantage. A Comparative Study of Manufacturing and Service Firms in Ghana. International Journal of Asian Social Science, 2013, 3(6):1293-1305. Also available at: http://www.aessweb.com/pdf-files/ijass-3(6)-12931305.pdf

Aghion, P. (2002). Schumpeterian growth theory and the dynamics of income inequality. Econometrica 70(3): 855-882. http://dx.doi.org/10.1111/1468-0262.00312. Available at http://nrs.harvard.edu/urm3:HUL.InstRepos: 3350067.

Aghion, P. and Tirole, J. (1994). Opening the Black Box of innovation. European Economic review, 38(3-4), 701710 .

Ali, K. A. M. \& Yunoh, M. N. M. (2015). The Effect of Business Innovation Capability on the Relationship between TQM and Malaysian SME Performance: A Conceptual Framework. Int'l Conference on Business, Marketing \& Information System Management (BMISM'15) Nov. 25-26, 2015 Paris (France).

Anderson, E. W. et. al (1994a). Customer Satisfaction, Market Share, and Profitability: Findings from Sweden. Journal of Marketing. Vol 58 (July 1994), 53-66. DOI: 10.2307/1252310

Baregheh, A. et al. (2012). Innovation in Food Sector SMEs. Journal of Small Business and Enterprise Development, Vol. 19 Iss: 2 pp. 300-321 http://dx.doi.org/10.1108/14626001211223919.

Bas, M. \& Paunov, C., 2018. The Unequal Effect of India's Industrial Liberation on Firms Decision to Innovate: Do Business Conditions Matter? Journal of industrial Economics, Volume LXVI, No. 1 March 2018. 00221821.

Bhattacharya, S. et. al. (1986). Sequential Research and the Adoption of Innovations. Oxford Economic papers 38(suppl. Nov.): 219-43 February 1986. DOI: 10.1093/oxfordjournal.oep.a041765.

Boehlje, M. Bröring, S. \& Roucan-Kane, M. (2009). Innovation in the Food and Agricultural Industries: A Complex Adaptive System. Working Paper \#09-19. December 2009. Dept. of Agricultural Economics, Purdue University.

Bröring, S. Cloutier, L.M. \& Leker, J. (2006). "The front end of innovation in an era of industry convergence the case of nutraceuticals and functional foods." R\&D Management Journal, 36 (5): 487-498.) Innovation in the Food and Agricultural Industries: A Complex Adaptive System. Working Paper \#09-19. December 2009. Dept. of Agricultural Economics.

Central Committee of the Communist Party of China, (n.d.). The $13^{\text {th }}$ Five-Year Plan for Economic and Social Development of the People's Republic of China (2016-2020). Compilation and Translation Bureau. Beijing, 
China).

Cronin J. J. Jr. Brady K. M. \& Hult T. M. G. (2000). Assessing the Effects of Quality, Value and Customer Satisfaction on Consumer Behavioural Intensions in Service Environments. Journal of Retailing, Volume 76(2) pp. 193-218, ISSN: 0022-4359.

Cross, P. (1989). Let's talk quality. New York: McGraw Hill.

Crosby, P. B. (1987). Quality Process Improvement management College (course materials). San Jose, CA: Philip Crosby Associates, Inc. In: Department of the Navy TQL Office, (1992). Three Experts on Quality Management.

Darroch, J. (2005). Knowledge management, innovation and firm performance. Journal of Knowledge Management, Vol. 9 No. 3, pp. 101-15.

Deming, W. E. (1986). Out of Crisis. Cambridge, MA: Massachusetts Institute of Technology, Center for Advanced Engineering. In: Department of the Navy TQL Office. (1992). Three Experts on Quality Management.

Development Policy Department. 2014. Diet Quality, Child Health, and Food policies in Developing Countries. Policy Research Working paper 7072. Development Policy Department, Development Economics Vice Presidency, World Bank Group.

Eckes, G. 2001. The Six Sigma Revolution: How general Electric and others Turned Process into profit. New York: Wiley.

Food and Drugs Authority, Ghana (2013). Code of Hygienic Practice for the Food Service Establishment in the Hospitality Industry. FDA/FSMD/CP-FSE/2013/03.

Food and Drugs Authority, Ghana (2014). Annual Report.

Food and Drugs Authority, Ghana (2015). Annual Report.

Food and Drugs Authority, Ghana \& World Health Organization. (2016). Manual for Foodborne Disease Surveillance in Ghana. FDA/FSMD/GL-FBD/2014/01

Food and Agriculture Organization of the United Nations (2015). Ghana: Country fact Sheet on Food and Agriculture policy Trends.

Feigenbaum, A. V. (1991). Total Quality Control, Inc. Singapore: Mc-Graw Hill.

Ghobadian, A. and Woo, H. S. (1996). Characteristics, benefits and short comings of four major quality awards, The international Journal of Quality and Reliability Management, Vol. 13 No. 2, pp. 10-44.

Global Innovation Index Report (2016).

Gitlow, H. S. \& Gitlow, S. J. (1987). The Deming guide to quality and competitive position. New York: Prentice Hall.

Golan, E. et. al. (2004). Traceability in the US Food Supply Chain. Agriculture Economic Report. pp 56. www.ers.usda.gov

Gunday et al., 2011. Effects of Innovation Types on Firm Performance. OJournal of International Production Economics, 133 (2), 662-676

Ishikawa, K. (1985). What is total quality control: the Japanese way? London: Prentice Hall.

Jansen, J. J. P. Van Den Bosch, F. A. J. \& Volberda, H. W. (2006). "Exploratory innovation, exploitative innovation, and performance, effects of organizational antecedents and environmental moderators", Management Science, Vol. 52 No. 11, pp. 1661-74.

Jovanovic, B. \& Nyarko, Y. (1996). Learning by Doing and the Choice of Technology, Econometrica 64, 12991310.

Juran Institute. (1996). Quality Improvement of Juran Institute.

Juran, J. \& Gryna, F. (1993). Quality Analysis and Planning. Quality Analysis Planning.

Juran, J. (1988). Juran on planning for quality. New York: The Free Press.

Karantininis, Sauer \& Furtan (2009). Innovation and integration in the agri-food industry. Food Policy 3592010 ) 122-120.

Kelchner, L, Theories of Total Quality Management. Available online at http://smallbusiness.chron.com/theoriestotal-quality-management-55715.html.

Kislev, Y. \& Shchori-Bachrach, (1973). N. American Journal of Agricultural Economics, Vol.55, No.1 (Feb., 1973), pp. 28-37. Oxford University Press on behalf of the Agricultural \& Applied Economics. http://www.jstor.org/stable/1238658. Accessed: 04-12-2016 18:55 UTC

Kmieciak R. Michna A. \& Meczynska A. (2012)."Innovativeness, empowerment and IT capability: evidence from SMEs", Industrial Management \& Data Systems, Vol. 112 Iss 5 pp. 707 - 728. Available at http://dx.doi.org/10.1108/02635571211232280. Assessed: 11 December 2016.

Kurtus, R., (28 May 2001). Basic Principles of Total Quality Management (TQM). http://www.school-forchampions.com/tqm/principles.htm\#.WLUKVIVOLVI

Leavengood, S. et. al. (2014). Exploring Linkage of Quality management to Innovarion. Total Quality Management, 2014, Vol. 25, No. 10, 1126-1140, http://dx.doi.org/10.1080/14783363.2012.738492 
Lamptey S. O. (2009). Quality Management System of Unilever Ghana Limited. A dissertation presented to St Clements University in Fulfillment of the Requirement for the Degree of Doctor of Philosophy in Strategic Management. Turks and Caicos Islands.

Manso, G. (2011). Motivating Innovation. The Journal of Finance, Vol. 66, No. 5 (October 2011), pp. 1823-1860. Wiley for the American Finance Association. Available online at http://www.jstor.org/stable/41305176. Accessed: 04-12-2016.

Marietta, O. W. Barra, C. \& Zotti, R. (2017). Innovation and University-Firm R\&D Collaboration in the European Food and Drink Industry. Journal of Agricultural Economics, Vol. 68, No. 3, 2017, 749-780.

Mauch, P. D. (2010). ). Quality Management: Theory and Application. Taylor and Francis Group, LLC pp31-32, 45

Ministry of Agriculture (2007). Food and Agriculture Sector Development Policy II.

Ministry of Finance and Economic Planning. (2018). The 2018 Budget Statement and Economic Policy of Ghana of the Government of Ghana for the 2018 Financial Year.

Mitchell, A. (1997). The quality pocketbook. London: Management Pocket Books.

Moscarini, G., \& Smith, L. (2001). The Optimal Level of Experimentation, Econometrica 69, 1629-1644.

Mowery, D. C. \& Rosenberg, N. (1979). The influence of market demand upon innovation: A critical review of some recent empirical studies, in: Research Policy, Vol. 8, pp. 102-153.

National Restaurant Association (2017). Restaurant industry Outlook. United States of America. Restaurant.org.

Ngambi, M. T. \& Nkemkiafu A. G. (2015). The Impact of Total Quality Management on Firm's Organizational Performance. American Journal of Management Vol. 15(4) 2015

Ollila, S. \& Yström, A. (2016). Beyond intermediation: the open innovation arena as ac actor enabling joint knowledge creation. International Journal Technology Management, Vol 72, No. 4, 2016. pp 273-295.

Ooi, K. B., et al. (2012). Does TQM support innovation performance in Malaysia's Manufacturing industry? Journal of Business Economics and Management, 13 (2) 366-393.

Powell, T. C. (1995). Total Quality Management as Competitive Advantage: A Review and Empirical Study. Strategic Management Journal (16.1). January

Psomas, E. Kafetzopoulos, D. \& Gotzamani, K. (2018). Determinants of company innovation and market performance. The TQM Journal. ISSN 1754-2731, Volume 30, Number 1 2018. Pp 54-73

Rama, R. (2008). (Ed) Handbook of Innovation in the Food and Drinks Industry, New York and London: The Howarth Press, Taylor \& Francis Group.

Rama, R. (1999). Innovation and Profitability of Global Firms. Testing for differences in the influence of the homebase. Environmental and Planning (31), 735-751.

Roberts, K. \& Weitzman, M. (1981). Funding Criteria for Research Development, and Exploration Projects, Econometrica 49, 1261-1288.

Sansawat, S. and Muliyil, V. (2012). Comparing Global Food Safety Initiative Recognized Standards.

Schumpeter, J. A. (1934). The Theory of Economic Development, Cambridge Massachusetts: Harvard University Press.

Suwandej, N. (2015). Factors Influencing Total Quality Management. 7th World Conference on Educational Sciences, (WCES-2015), 05-07 February 2015, Novotel Athens Convention Center, Athens, Greece. Procedia - Social and Behavioral Sciences 197 (2015) 2215 - 2222. Available online at www.sciencedirect.com

Talib et, al. (2011). Best Practices of Total Quality Management Implementation in Health Care Settings. Health Marketing Quarterly.

WHO \& FAO (n.d). Assuring Food Safety and Quality: Guidelines for Strengthening National Food Control Systems. FAO and WHO Joint Publication

Zapata-Cantu, L. et al. (2007). E-HRM in Mexico: Adopting Innovations for Global Competitiveness. International Journal of Manpower. 28(5): 418-434. DOI: 10.1108/04137720710778402.

Zhang Bo Tao Qiuyan (2012). Research of SMEs' technology innovation model from multiple perspectives. Chinese Management Studies, Vol. 6 Iss 1 pp. $124-136$. Available at: http://dx.doi.org/10.1108/17506141211213825. Assessed: 11 December 2016.

Zhou et al., (2005). Developing Strategic Orientation in China: Antecedents and Consequences of Market and innovation orientation. Journal of Business Research, 58 (8), pp. 1049-1058 FDA/FSMD-GL-FBD/2014/01 